\section{Simple basic model for concrete and its application \\ 1. Content indicators of concrete mixtures and mixing plant observations}

\author{
GyULA PEKÁR - private consultant - alba-qualit@hdsnet.hu
}

Érkezett: 2013. 06. 06. - Received: 06. 06. 2013. - http://dx.doi.org/10.14382/epitoanyag-jsbcm.2013.12

\begin{abstract}
One of the constantly recurring tasks of concrete engineering is to examine the effects and interactions of the materials which concrete mixtures are composed of. When analysing the effects and interpreting the interactions, it is often worth going back to the basics and reconsidering the models that we use to interpret our findings. It may be necessary to refine them, so that the models we use as the basis for concrete mix design keep pace with the developments brought about by the appearance of new materials. The paper introduces a simple basic model for concrete mixtures that covers dimensionless content indicators which can determine the composition of concrete in a clear and predictable way. The content indicators have an impact on the performance properties of the concrete, therefore, specific direct observations were made and measurements were carried out at a concrete mixing plant. The observations provided data input for the simple basic model for concrete mixes, which, by introducing dimensionless concrete composition content indicators, offers a new way of examining the effects that influence the performance properties of fresh and hardened concrete mixes.

Keywords: concrete technology, concrete mix design, concrete composition content indicators
\end{abstract}

Gyula PEKÁR Chemical engineer (University of Veszprém, 1981). Active in the construction industry since 1984 , first as a research engineer, and later as head of the laboratory at ARÉV, which was at the time the leading construction company in Székesfehérvár. From 2000, as a private consultant, he prepared enterprises for the implementation and operation of a number of $\mathrm{QA}$ systems (ISO 9001, ISO 14001, ISO/IEC 17025). From 2007-2013 he was a part-time engineering inspector at the state-owned ÉMI (Non-Profit Limited Liability Company for Quality Control and Innovation in Building). With the support of ÉMI, he carried out a research project, originally in conjunction with the Augusztin Concrete Manufacturing Company (Zamárdi), to establish the correlations between concrete compositions and the performance indicators of the set concrete, by recording observations of concrete mixes during their manufacture at the mixing plant. In 2011, he was invited by the Hungarian Institute for Transport Sciences to participate in research into low-shrinkage floor concrete compositions.

\section{Introduction}

There are certain phenomena sometimes in concrete technology which do not fit in the existing models (or do not fit in very easily), as can be illustrated by the following three examples on the effects of cements, additions (supplementary materials) and water-reducing admixtures.

In the Hungarian Concrete Almanac 2005, Szalai, Huszár and Spránitz indicated that in cases of low water-cement ratios $(w / c<0.4)$ a greater compressive strength can be measured for certain CEM 32.5 cements than for CEM I 42.5 and CEM I 52.5 cements, which seems to contradict the widely known equations for estimating compressive strength [1]. Own tests of the authors of present paper confirm this: in the case of mixtures where $\mathrm{w} / \mathrm{c}=0.2$, it was found that specimens made of CEM III/B $32.5 \mathrm{~N}-\mathrm{S}$ type cement after a period of 28 days had higher compressive strength $\left(136.7 \mathrm{~N} / \mathrm{mm}^{2}\right)$ than that of the mixture made with CEM I 42.5 cement and cured under identical conditions $\left(129.8 \mathrm{~N} / \mathrm{mm}^{2}\right)$. Could there possibly be a method of estimating compressive strength which is able to predict these apparently contradictory results?

Zsigovics - the first researcher in Hungary who studied the effects of additions on concrete mixes - reported another interesting observation: a series of concrete mixes was prepared using identical dosage of cement $\left(350 \mathrm{~kg} / \mathrm{m}^{3}\right)$, identical water-cement ratio $(\mathrm{w} / \mathrm{c}=0,5)$ and identical quantity of water-reducing admixture $(1.6 \%)$, but with the content of limestone powder varying between $70 \mathrm{~kg} / \mathrm{m}^{3}$ and $370 \mathrm{~kg} / \mathrm{m}^{3}$. Increasing the amount of limestone powder to its upper limit has increased the compressive strength by $55 \%$, while the consistency measured using flow table test has been increased by $20 \%$ [2]. How can we explain this?

Determining the consistency of concrete mixtures could be also difficult when effective water-reducing admixtures are used to achieve the required results. It is worth here taking a look at Sulyok's reports considering two major investigations in Hungary: the Budapest Metro and the M6 Motorway [3,4]. Spránitz provides a very thorough survey of the discrepancies appearing in the effects of different admixtures and the combined effects of additions in cement pastes [5]. Research findings and practical experience both confirm that the effect of waterreducing admixtures depends on the prevailing compositional (environmental) properties of the concrete mixtures. In addition to the type of admixture, exactly when and to what extent the effect takes place depends, for example, on the paste content of the concrete, the water content of the paste and the grading (specific surface area) of the aggregate. The question is "simply" what are the specific relationships that describe the consistency of fresh concrete mixtures with or without admixtures?

Is it possible that the phenomena and problems referred to above are interrelated? They probably are, and they can ultimately be traced back to the compositional and environmental properties (conditions) of the concrete mixtures. If this really is the case, then there must be a model based on the compositional properties of concrete, into which we can fit the phenomena that are mostly dealt with today on a purely empirical basis. The present work is intended to present the basis of such a model.

\section{A brief review of the paste approach in concrete technology}

Both European standard EN 206-1 and Hungarian standard MSZ 4798-1:2004 (which is a National Application Document to EN 206-1) define concrete as "... a material formed by mixing cement, coarse and fine aggregates and water, with or without the incorporation of admixtures or other additions..." This listing of the constituent materials of concrete is almost too literal. It is also rather thought-provoking that this extensive standard 
only mentions the word paste on very rare occasions (perhaps eight times in all). This is especially peculiar given the whole life work of Powers [6], as well as the fact that Ujhelyi, in his pioneering research on concrete engineering in Hungary, has not only used the concept of paste for decades, but has also carried out systematic studies of the effects of paste on the performance properties of concrete mixtures [7]. The paste approach was published in the technical directive MÉASZ ME 04-19:1995, again as a result of work by Ujhelyi and his colleagues [8], and it remains to this day a vital resource of information for all concrete engineers in Hungary.

The paste approach is therefore with us, even if it has not yet achieved the rank of being recognised in the standard, and it is used by engineers in the forefront of concrete research and practice. In an article published several years ago, Spránitz wrote about the composition of concrete mixtures by stating the volume ratios of paste content and air content, including the volume ratio of water and powder (particles below 0.125 $\mathrm{mm}$ ) in the paste, with the additions calculated together with the other powder materials [9]. The traditional water-cement ratio was also given in the paper, so that an expert can easily calculate the recipe from his data. However, the main issue here is not the recipe, but the approach. If we say that the concrete mixture contains 530 litres of paste per $1 \mathrm{~m}^{3}(\mathrm{x}=0.56$ water/ fine particle volume ratio, $\mathrm{w} / \mathrm{c}=0.24$ traditional water-cement ratio), in which $70 \%(\mathrm{v} / \mathrm{v})$ of the paste powder is cement, and also there is 10 litres of air in the concrete (from which we get a volume of 460 litres of aggregates), this reveals much more about the structure of the concrete than by listing the recipe like the ingredients in a cookery book. The same concrete composition can also be described as $c=792 \mathrm{~kg} / \mathrm{m}^{3}$, mixture of additions $=298$ $\mathrm{kg} / \mathrm{m}^{3}$, water + admixture $=191 \mathrm{~kg} / \mathrm{m}^{3}$, aggregate $=1219 \mathrm{~kg} / \mathrm{m}^{3}$, but whereas the first description tells us immediately that we are dealing with a mixture very rich in paste which will need to be strongly plasticized (and which will produce certain side effects when it is poured into the form), the cookery book list tells us very little indeed, unless we can mentally work out the concrete composition components into a structure in our mind.

We should therefore move on from a definition of (and approach to) concrete which is based on a listing of the components, and, building on the experiences gained so far in the area of research into high performance concretes, we should apply a simple basic model which, although not entirely without precedent, still requires further work to clear up the details and to refine its form. This model can help to identify the effects on certain performance properties of fresh and hardened concretes, and to better understand certain interrelationships, as well as serving as the basis for designing concrete compositions.

\section{The simple basic model of concrete mixtures}

Below we will consider the fresh concrete mixture as a macroheterogeneous system which - at least from a macroscopic aspect - consists of three clearly distinct phases:

- paste, which is in itself a heterogeneous system (microheterogeneous suspension), and which behaves in fresh concrete mixtures as a quasi-fluid dispersing agent,
- aggregates, which are a mass of solid (insoluble) macrosized particles/granules, and which are distributed in the paste as a dispersed phase,

- $\quad$ air, as gaseous phase, which is generally present as voids as a result of incomplete compaction, although there are also conscious engineering processes whereby small air bubbles are introduced intentionally into the system (the paste) as a dispersed phase.

The composition of a given concrete mixture - for given paste and given aggregate (mixture) - is clearly given by two independent data - selected as appropriate - as per Eq. (1):

$p+a+l=1$

where $p, a, l$ are the volumetric proportions of paste ( $p)$, aggregate (a) and air $(l)$ in the concrete, and where the aggregate may also be a mixture of a number of components $n_{A G} \geq 1$, with the restriction on the amount of the dose, Eq. (2):

$a=\sum_{i=1}^{n A G} a_{i}=1-l-p \leq a_{\max }$

where $a_{\text {max }}$ is the maximum volume ratio of aggregate that can be compacted into the volumetric unit of the concrete in the given compositional condition (equivalent to the amount designated by Ujhelyi as $\mathrm{V}_{\mathrm{a} 0}$ in [8], but expressed here as a dimensionless proportional figure), and $a_{i}$ is the $i$-th volume ratio of the aggregate component in the component.

If the known or recorded $\alpha_{A G i}$ volumetric proportions of the aggregate are given, any $a_{i}$ component can be expressed, Eq. (3):

$a_{i}=\alpha_{A G i} \cdot a$, where $\sum_{i=1}^{n_{A G}} \alpha_{A G i}=1$

If instead of the $\alpha_{A G i}$ volumetric proportion we insist on using the widespread $\alpha_{M^{\prime} A G i}$ mass proportions, then the figure for volumetric proportion in Eq. (3) may be replaced by Eq. (4):

$\alpha_{A G i}=\frac{\frac{\alpha_{M, A G i}}{\rho_{A G i}}}{\sum_{i=1}^{n_{A G}} \frac{\alpha_{M, A G i}}{\rho_{A G i}}}$, where $\sum_{i=1}^{n_{A G}} \alpha_{M, A G i}=1$

where $\rho_{A G i}$ is the particle density of the $i$-th aggregate in its condition when it is included in the mixture (in practice there are differences in the densities of different aggregate fractions and types, also depending on the amount of absorbed water, and these must be accounted for in the design).

\section{The role of paste in the simple basic model for concrete mixtures and relationships}

In the simple basic model for concrete mixtures, paste is considered (on the basis of its macroscopic properties and effects) as a phase of the concrete mixture that behaves as a quasi-fluid, in which (as it is itself a suspension) we can distinguish between different phases:

- $\quad$ the fluid phase (i.e. a mixture of water + admixtures; solution), which is the dispersing agent of the solid paste powder, and 
- the solid phase (i.e. the paste powder), which is dispersed in the fluid as a dispersed phase as a mixture of the fine particle content of the cement + additions + aggregates, and also

- the gaseous phase (air), which may be present both as entrapped and or entrained air as a dispersed phase (and is present in practice).

We should clarify, when referring to the paste powder, that the paste powder includes the total of all solid state concrete components which have a particle size below a given limit $(0.063$ $\mathrm{mm}$ ), regardless of whether they have hydraulic properties or not, or whether they have been intentionally measured into the mixture or have just added to the fresh concrete mixture, for example as a part of the aggregate. The limit for particle size $(0.063 \mathrm{~mm})$ is arbitrary, although this has no effect on the principle of the simple basic model (the difference between the paste powder and the aggregate appears not so much in the particle size as in the difference of two magnitudes between their specific surface areas).

It is worth stating some of the basic relationships regarding the composition of pastes. The volumetric composition of a paste of a given quantity is given by Eq. (5):

$p=f+z=z \cdot(1+x)$, where $x=\frac{f}{z}$

where $f$ and $z$ are respectively the unabsorbed (free) fluid (mostly water) and the volume proportion of the paste powder in the concrete, and $x$ is the volumetric ratio between the fluid and the paste powder, which functions are similar to the traditional water-cement ratio.

In addition to cement the paste powder may contain a $n_{K} \geq 0$ quantity of addition components as per Eqs. (6) to (7):

$z=\frac{p}{1+x}=c+\sum_{i=1}^{n K} k_{i}=c+k$

$k_{i}=\alpha_{K i} \cdot k$, where $\sum_{i=1}^{n K} \alpha_{K i}=1$

where $c, k$, and $k$, are respectively the volumetric ratios of cement, the $i$-th addition component and the total additions in the concrete, and $\alpha_{K i}$ is the volumetric ratio of the $i$-th component in the additions. If, instead of the volumetric ratio $\alpha_{K i}$ we would rather use the mass ratio $\alpha_{\mathrm{M}, K i}$, then (taking the particle density $\rho_{K i}$ of the additions into account) we must recalculate according to Eq. (4) and use this in Eq. (7) in the place of $\alpha_{K i}$.

In addition to water the fluid phase of the paste may contain a $m \geq 0$ quantity of admixture components, as a perfect analogy of Eq. (6), see Eq. (8):

$f=\frac{p}{1+x} \cdot x=w+\sum_{i=1}^{m} a d_{i}=w+a d$

where $w, a d_{i}$ and ad are respectively the volumetric ratios of unabsorbed water, the $i$-th admixture component and the total admixtures in the concrete.
If the quantity of the $i$-th admixture is expressed as the proportion $\lambda_{A D i}$ of the volume of paste powder, then Eqs. (9) and (10) can be formulated:

$\lambda_{A D i}=\frac{a d_{i}}{z}$

$a d=\sum_{i=1}^{m} a d_{i}=z \cdot \sum_{i=1}^{m} \lambda_{A D i}=\frac{p}{1+x} \cdot \sum_{i=1}^{m} \lambda_{A D i}$

In order to verify the composition criteria according to Hungarian standard MSZ 4798-1:2004, it is important to take into consideration the combined volumes of water in the admixtures when calculating the water-cement ratio, which can be done by Eq. (11):

$w_{A D}=\sum_{i=1}^{m} \frac{a d_{i} \cdot \rho_{A D i} \cdot\left(1-s z_{i}\right)}{\rho_{w}}=\frac{p}{1+x} \cdot \sum_{i=1}^{m} \frac{\lambda_{A D i} \cdot \rho_{A D i} \cdot\left(1-s z_{i}\right)}{\rho_{w}}$

where $w_{A D}$ is the amount of water in the admixture as a proportion of the volume of the concrete, $\rho_{A D i}$ and $\rho_{w}$ are respectively the density of the admixture and the water in the given environmental condition, and $s z_{i}$ is the dry matter content of the $i$-th admixture expressed as a mass ratio (manufacturers usually provide the information as a percentage of mass).

Finally, proportional parameters can be introduced for paste powder components, Eq. (12):

$\beta_{k}=\frac{k}{c}$, or rather $\chi_{c}=\frac{c}{z}=\frac{1}{1+\beta_{k}}$

where $\beta_{k}$ and $\chi_{c}$ are respectively the volumetric ratios of additions/cement and of cement/paste powder.

\section{Content indicators used in the simple basic model for concrete mixtures}

If a concrete mixture does not contain admixtures or additions, so $\chi_{c}=1$ [i.e. $\beta_{k}=0$ ] and $\lambda_{a d}=0$, then the ratios $p$ (volumetric ratio of paste in the concrete), $x$ (liquid-powder volumetric ratio in the paste) and $l$ (volumetric ratio of air in the concrete) - in the case of given concrete component materials - clearly determine the composition of the concrete.

If a concrete mixture also contains additions and/or admixtures, then in order to be able to clearly determine the composition of the concrete we also need to know two additional ratios: $\chi_{c}$ (proportion of cement in the paste powder) and $\lambda_{A D}$ (the sum of all $\lambda_{A D i}{ }^{-s}$, the combined volume ratio of all admixtures compared with the paste powder). Instead of $\chi_{c}$ we may opt to use the proportional figure $\beta_{k}$ (the sum of all $\beta_{k i}-\mathrm{s}$, the combined volume ratio of all additions compared with the cement), as they can both be derived from each other using Eq. (12).

In the case of $f i x e d \alpha_{K i}, \lambda_{A D i}$ and $\alpha_{A G i}$ composition proportions of multi-component concrete constituents (additions, admixtures and aggregates), the five dimensionless ratios $\left(p, x, l, \chi_{c} \lambda_{A D}\right)$ are necessary and sufficient to describe the composition of concrete mixtures, and therefore these ratios may also be regarded as concrete composition content indicators. Later we will not only use these parameters to describe (and compare) concrete 


\begin{tabular}{|c|c|c|c|c|c|c|c|c|c|c|c|}
\hline \multirow[b]{2}{*}{ Structure } & \multirow[b]{2}{*}{ Constituents } & & & & & & \multirow{2}{*}{$\begin{array}{c}\text { densities } \\
{\left[\mathrm{kg} / \mathrm{m}^{3}\right]}\end{array}$} & \multirow{2}{*}{\multicolumn{2}{|c|}{ equations }} & \multicolumn{2}{|c|}{ composition } \\
\hline & & \multicolumn{5}{|c|}{ content indicators, ratios } & & & & {$\left[\mathrm{kg} / \mathrm{m}^{3}\right]$} & {$\left[l / \mathrm{m}^{3}\right]$} \\
\hline \multirow{4}{*}{ paste } & Water, w & \multirow{2}{*}{ f } & \multirow{4}{*}{$\begin{array}{l}\infty \\
+ \\
2 \\
0 \\
\| \\
N \\
+1 \\
0\end{array}$} & \multirow{4}{*}{ 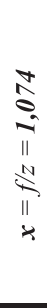 } & & & 1000 & (13) $\mathrm{W}\left[\mathrm{kg} / \mathrm{m}^{3}\right]=$ & $\frac{p}{1+x} \cdot\left(x \cdot \rho_{w}-\sum_{i=1}^{m} \lambda_{A D i} \cdot \rho_{A D i}\right) \cdot V_{b}$ & 175 & 175 \\
\hline & admixture, ad & & & & $\lambda_{A D}=a d / z$ & 0,030 & 1100 & (14) $\mathrm{ADi}\left[\mathrm{kg} / \mathrm{m}^{3}\right]=$ & $\lambda_{A D i} \cdot \frac{p}{1+x} \cdot \rho_{A D i} \cdot V_{b}$ & 5,54 & 5,03 \\
\hline & cement, $\mathbf{c}$ & \multirow{2}{*}{$\mathrm{z}$} & & & $\chi_{c}=c / z$ & 0,681 & 3065 & (15) $\mathrm{C}\left[\mathrm{kg} / \mathrm{m}^{3}\right]=$ & $\chi_{c} \cdot \frac{p}{1+x} \cdot \rho_{c} \cdot V_{b}$ & 350 & 114 \\
\hline & additions, $\mathbf{k}$ & & & & $\beta_{k}=k / c$ & 0,468 & 2710 & (16) $\mathrm{Ki}\left[\mathrm{kg} / \mathrm{m}^{3}\right]=$ & $\alpha_{k i} \cdot\left(1-\chi_{c}\right) \cdot \frac{p}{1+x} \cdot \rho_{K i} \cdot V_{b}$ & 145 & 54 \\
\hline \multirow{3}{*}{ aggregates } & $0 / 4$, a1 & \multirow{3}{*}{\multicolumn{3}{|c|}{$a=1-l-p=0,631$}} & $\alpha_{A G I}$ & $\mathbf{0 , 5 0}$ & 2640 & \multirow{3}{*}{ (17) $\mathrm{AGi}\left[\mathrm{kg} / \mathrm{m}^{3}\right]=$} & \multirow{3}{*}{$\alpha_{A G i} \cdot(1-p-l) \cdot \rho_{A G i} \cdot V$} & 833 & 316 \\
\hline & $4 / 8, \mathbf{a} 2$ & & & & $\alpha_{A G 2}$ & 0,35 & 2640 & & & 583 & 221 \\
\hline & $8 / 16$, a3 & & & & $\alpha_{A G 3}$ & 0,15 & 2640 & & & 250 & 95 \\
\hline air (void) & $l$ & \multicolumn{5}{|c|}{$l=0,021$} & 1,29 & $\mathrm{~L}\left[\mathrm{~kg} / \mathrm{m}^{3}\right]=$ & $l \cdot \rho_{l e v} \cdot V_{b}$ & $\mathbf{0}$ & 21 \\
\hline
\end{tabular}

Table 1. Composition of concrete with content indicators $p=0.348, x=1.074, l=0.021, \lambda_{a d}=0.030, \chi_{c}=0.681$ from concrete components 1. táblázat Egy $p=0.348, x=1.074, l=0.021, \lambda_{a d}=0.030, \chi_{c}=0.681$ állapotjelzöjü beton összeállitása a betonalkotókból

compositions; we will also examine the relationships between the content indicators and certain performance properties of fresh and hardened concretes. Of course, the performance properties of concretes are not exclusively influenced by the concrete composition content indicators, but also by the actual physical properties of the concrete constituents. The model based on concrete composition content indicators does, however, offer a basic framework for interpreting the properties of concretes, and supports a way of assessing the similarities of different concrete compositions (the five independent content indicators provide virtually infinite possibilities, so there is no need to worry that there will be no more areas in concrete engineering that require further research).

An example is presented as an illustration of a concrete mixture with given content indicators $p, x, l, \chi_{c} \lambda_{\text {adi }}$, where the material properties of the concrete components are given. Calculations of a concrete composition with a volume of $\mathrm{V}_{\mathrm{b}}=1$ $\mathrm{m}^{3}$ from the content indicators are presented in Table 1, while the pie chart in Fig. 1 shows the quantities $\mathrm{C}, \mathrm{K}, \mathrm{W}, \mathrm{AD}_{\mathrm{i}}, \mathrm{AG}_{\mathrm{i}}$ of known concrete components that are to be added to $1 \mathrm{~m}^{3}$ of concrete mixture.

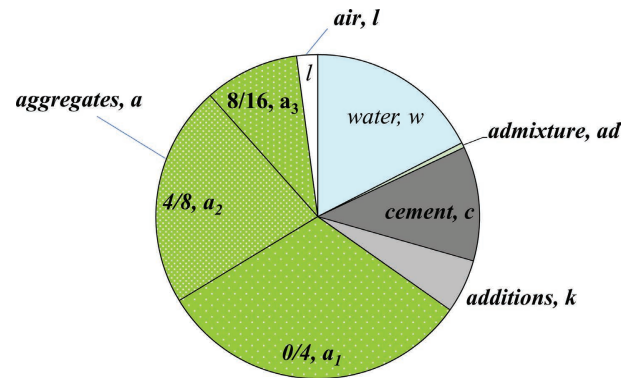

Fig. 1. Volumetric composition of concrete with content indicators $p=0.348, x=1.074, l=0.021, \lambda_{a D}=0.030, \chi_{c}=0.681$

1. ábra A $p=0,348, x=1,074, l=0,021, \lambda_{A D}=0,030, \chi_{c}=0,681$ állapotjelzőjü beton térfogatos összetétele

\section{Observations at a concrete mixing plant}

The author of present paper worked together with Augusztin Betongyártó Ltd. concrete mixing plant on various projects since 2007. The initial task was simply to conduct maintenance on the mixing recipes used at the concrete mixing plant of Augusztin Betongyártó Ltd., which was done mainly in line with the former Hungarian standard MSZ 4719:1982. The maintenance was needed due to changes that had taken place in the aggregates used at the mixing plant, but the possibility of changing the types of cement used and introducing certain additions was also raised. The original task was continued in $R+D$ cooperation with new objectives under the support of ÉMI Nonprofit Ltd. from 2009.

Nevertheless, a series of observations at a mixing plant does not need much preparation to carry out, however, there is a need for organisation and discipline. When the aim is to collect a mass of data which can be used for proper analysis and for subsequent evaluations, it is important to extend the level of observation over the level of a regular mixing plant inspection.

\section{Conditions of the observations}

The conditions for carrying out the mixing plant observations were defined as early as 2008 as follows:

- The plant should be equipped with a system of certified scales for accurately weighing in the concrete constituents.

- For every batch of concrete mix that is subject to observation, the dosage of every single constituent in the concrete must be known and recorded. In the case of aggregate fractions, the measurement to be recorded is of the aggregate at the time of mixing, that is, the aggregate is wet. Even relatively small doses of admixtures must not be neglected. In view of the fact that individual deliveries of concrete are often composed of more than one mixing item, it is needed to include summarised data of the mixing items in the database of deliveries.

- Certain physical properties of the concrete constituent materials must be continuously known or monitored, at least the physical properties which are described in detail later in this paper. 
- For every sample taken from the concrete mix deliveries which are included in the observations, at least the following tests and data must be recorded:

- inspection of consistency of the sample within half hour of the start of the mixing process, with at least one measurement of consistency defined (such as flow table and/or slump),

- concrete temperature, air temperature, air humidity, wind speed if necessary,

- determination of the water content of the sample as the mass proportion or mass percentage of the fresh concrete $\left(w_{\text {concrete }}\right)$,

- $\quad$ at least three sample cubes with dimensions of $150 \mathrm{~mm}$ must be taken, and the mass of the fresh concrete compacted into the mould must be measured (the $\rho_{\text {concrete }}$ fresh particle densities can also be determined from this),

- the air content of the samples must be inspected, which in theory directly tells us content indicator $l$, although it is always worth carrying out calculations of this to check that the particle densities and water contents of the samples confirm the result of the air-content inspection,

- after removal from the mould after one day, specimens must be submerged in water until the 28th day (in spite of all views to the contrary, only wet, saturated $\mathrm{Ca}(\mathrm{OH})_{2}$, solution storage provides curing conditions that may be regarded as identical),

- the dimensions of the sample cubes must be measured after they are taken out from the moulds, or at the latest before the strength test,

- repeat the measurement of the mass before the compressive strength test (compared with the fresh concrete, the concrete which is kept submerged in water always absorb more water [10], which could be a significant parameter typical of the type of cement),

- Compressive strength test at a known age (in general at 28 days; as was in present analyses).

In addition to the tests listed above, additional inspections may also be carried out: these may include inspections of the consistency endurance and early-age and mature compressive strength at different ages and in different environmental conditions, the splitting tensile strength tests, the deformation properties, examination of resistance to certain (material) transport processes, etc. To conduct the tests it is necessary to have properly trained staff and certified measuring instruments, or if these are not available it is recommended to use the services of a properly equipped and, if possible, accredited testing laboratory.

In theory, the number of tests that can be carried out is infinite, but for the simple basic model one criterion is always essential: the concrete composition content indicators of the concretes being inspected must always be known or calculable, in addition to the physical and other material properties of the concrete constituents that must also be known. Here the question arises of how concrete composition content indicators are derived from the mixing plant observation data and the known or measured physical properties.

\section{Defining concrete composition content indicators from observed data}

Before the definition of the concrete composition content indicators, list of observed data available for calculating the content indicators is given.

\subsection{Dosage (weighed) quantities}

$K_{\text {virt }}(\mathrm{kg})$ total measured additions, $c(\mathrm{~kg})$ measured cement, $A G_{\text {virt }}(\mathrm{kg})$ total measured wet aggregates, $W_{\text {virt }}(\mathrm{kg})$ measured added water, $A D(\mathrm{~kg})$ total measured admixtures. The virt (virtual, apparent) index in the quantities refers to the fact that there are (or may be) parts present in the concrete constituents, which belong to different phase components of the concrete. For example, in the case of the additions, besides the parts that belong to the paste powder phase there are also particles above $0.063 \mathrm{~mm}$, which belong to the aggregate phase, while there are at the same time particles in the aggregate below $0.063 \mathrm{~mm}$, which belong to the paste powder. Moreover, in the aggregates there is also water present, which must be accounted for in addition to the water which is added when the batch is mixed.

The dosage (weighed) results clearly provide the dosage mass ratios $\left(\alpha_{M, \text { Kvirt,i }}, \alpha_{M, A G v i r t, j}, \alpha_{M, A D, k}\right)$ for each type of concrete constituent, where the sum of the ratios is unity as: $\Sigma \alpha_{\mathrm{M}, \mathrm{Kvirt}, \mathrm{i}}=$ $\Sigma \alpha_{\mathrm{M}, \mathrm{AGvir}, \mathrm{j}}=\Sigma \alpha_{\mathrm{M}, \mathrm{AD}, \mathrm{k}}=1$.

\subsection{Physical properties of the concrete constituents}

- The moisture contents of the aggregate fractions ( $\mathrm{w}_{\mathrm{AG}, \mathrm{j}}$; $\mathrm{m} \%)$ in the condition they are in when mixed into the concrete.

- The fine particle $(<0.063 \mathrm{~mm})$ contents of the additions and the aggregate fractions as a mass proportion $\left(\phi_{K, i}\right.$, $\left.\phi_{A G, j} ; \mathrm{m} \%\right)$.

- The particle densities of the aggregate fractions $\left(\mathrm{kg} / \mathrm{m}^{3}\right)$, at the very minimum for fine $(<0.063 \mathrm{~mm})$ and coarse $(>0.063 \mathrm{~mm})$ particles $\left(\rho_{A G^{\prime} \text { coarse }, j}, \rho_{A G^{\prime} \text { fine }, j}\right)$.

- The relative densities of the cement, the additions, the mixing water and the admixtures $\left(\rho_{\mathrm{c}}, \rho_{\mathrm{K}, \mathrm{i}}, \rho_{\mathrm{w}}, \rho_{\mathrm{AD}, \mathrm{k}}\right.$; $\mathrm{kg} / \mathrm{m}^{3}$ ) in their condition at the time of mixing. For cements and additions the calculations are made using their dry densities, while for aggregates it is sensible to use the surface-dry, water-saturated density.

- It is a good idea to collect data on the short-term water absorption rates of the solid concrete constituents (cement, additions and aggregates) ( $\left.\mathrm{sw}_{\mathrm{c}}, \mathrm{sw}_{\mathrm{K}, \mathrm{i}}, \mathrm{sw}_{\mathrm{AG}, \mathrm{j}} ; \mathrm{m} \%\right)$, because their impact may be discernible in the case of concretes with a low water-cement ratio. When processing and evaluating the data from the observations at the mixing plant within the spectrum of conventional concretes, we generally did not account for this impact.

- The dry matter contents of admixtures ( $\left.\mathrm{sz}_{\mathrm{i}} ; \mathrm{m} \%\right)$. 


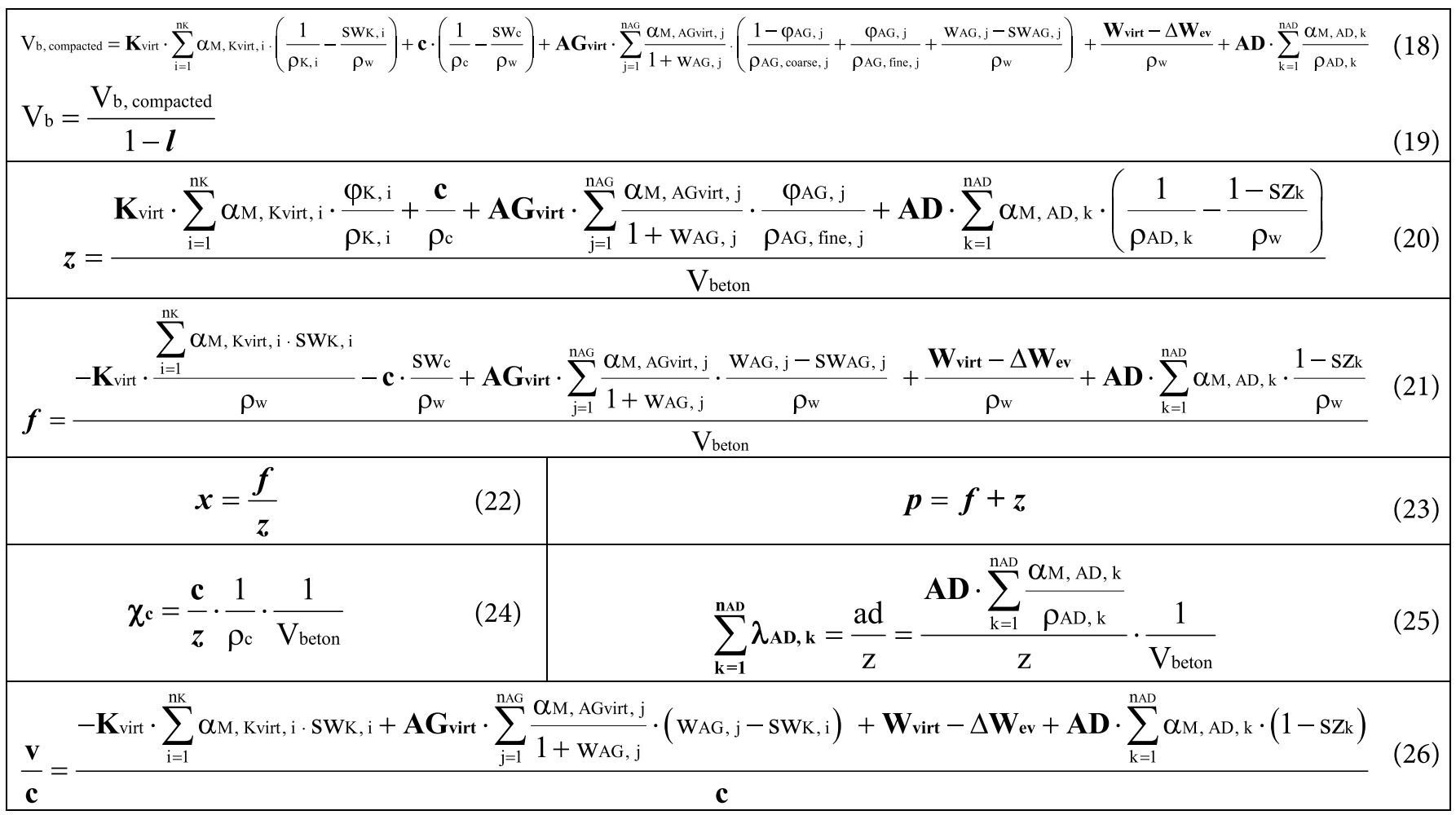

Table 2. Equations for calculating concrete composition content indicators from the dosages of concrete constituents and data on their physical properties 2. táblázat A betonösszetételi állapotjelzők számítási képletei a betonalkotók adagolási mennyiségeiböl és fizikai jellemzőinek adataiból

\subsection{Measurements used for calculating the concrete composition content indicators}

- The measured masses $(\mathrm{kg})$ of the components of the fresh concrete batch, in line with the first paragraph of section 8.1.

- In periods of hot weather it is sensible to measure, estimate and account for the loss through evaporation $\Delta \mathrm{W}_{\mathrm{ev}}$ (kg) experienced by the mixed items.

- The measured air content of the fresh concrete, $l$ as a volume ratio of the concrete (directly measured content indicator).

8.4 Measurements used both for calculating the concrete composition content indicators and for checking the calculations

- Particle density as measured in the fresh concrete $\rho_{\text {concrete }}$ $\left(\mathrm{kg} / \mathrm{m}^{3}\right)$.

- Water content as measured in the fresh concrete $\mathrm{w}_{\text {concrete }}$ (m\%).

\subsection{Calculating the concrete composition content indicators}

The auxiliary variables used in the calculations can be derived by Eqs. (18) to (21); the four concrete composition content indicators (apart from $l$ ) and the traditional (effective) water-cement ratio can be derived using equations (22) to (26). The interrelationships - without detailed calculations - are presented in Table 2.
When defining the concrete composition content indicators it is important also to check if the measured values (i.e.: measured density, $\rho_{\text {concrete }}, \mathrm{kg} / \mathrm{m}^{3}$ and measured water content $\left.\mathrm{w}_{\text {concrete }}, \mathrm{m} \%\right)$ of the fresh concrete match the values calculated using Eqs. (27) and (28) below:

$$
\begin{aligned}
& \rho_{\text {concrete, calc }}=\frac{\mathbf{K}_{\text {virt }}+\mathbf{c}+\mathbf{A} \mathbf{G}_{\text {virt }}+\mathbf{W}_{\text {virt }}-\Delta \mathbf{W}_{\text {ev }}+\mathbf{A D}}{\mathrm{V}_{\mathrm{c}}}
\end{aligned}
$$

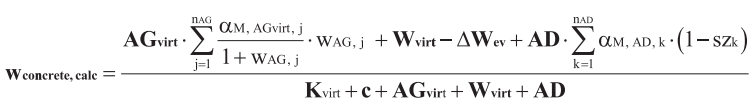

If there is disagreement then the physical properties of the materials should be checked, as should the measured data, in particular the moisture contents of the aggregates and the air content $\left(\mathrm{w}_{\mathrm{AG}, \mathrm{j}}\right.$ and $\left.l\right)$, and the calculations should be performed again using the corrected data. If it is not practicable to repeatedly measure the air content then $l$ can be calculated using equations (18), (19) and (27). The calculated concrete composition content indicators may only be regarded as acceptable if the calculated density and water content do not deviate by more than $3 \%$ from the measured values, and if they are also consistent with the measured values.

Table 3 presents a possible example of how the dosage quantities and physical properties of the concrete constituents can be collected and recorded systematically for a particular batch of concrete. In the white fields at the bottom of the table we have highlighted the content indicators as calculated from the equations introduced, which clearly define the structural composition of the concrete in accordance with the basic model presented. 


\begin{tabular}{|c|c|c|c|c|c|c|c|c|c|c|c|}
\hline \multicolumn{2}{|c|}{ Components of concrete } & \multicolumn{3}{|c|}{$\begin{array}{l}\text { Weight of coponents for } \\
\text { the batch }\end{array}$} & \multicolumn{2}{|c|}{ Ratios in components } & $\begin{array}{c}\text { Fines } \\
\text { (particles smaller } \\
\text { than } 0.063 \mathrm{~mm} \text { ) }\end{array}$ & \multicolumn{2}{|c|}{ Dried densities } & $\begin{array}{c}\text { Moisture } \\
\text { content }\end{array}$ & $\begin{array}{l}\text { Absorption of } \\
\text { water }\end{array}$ \\
\hline marking & name & \multicolumn{2}{|c|}{$\left[\mathrm{kg} / \mathrm{m}^{3}\right]$} & {$\left[\mathrm{m}^{3} / \mathrm{m}^{3}\right]$} & \multicolumn{2}{|c|}{ marking value } & marking $[\mathrm{m} \%]$ & \multicolumn{2}{|c|}{ marking $\left[\mathrm{kg} / \mathrm{m}^{3}\right]$} & marking $[\mathrm{m} \%]$ & marking $[\mathrm{m} \%]$ \\
\hline $\mathbf{W}_{\text {virt }}$ & drilled water & \multicolumn{2}{|c|}{285} & & & & & \multicolumn{2}{|l|}{$\rho_{w}=$} & & \\
\hline AD & $\begin{array}{c}\text { water reducing } \\
\text { admixture }\end{array}$ & \multicolumn{2}{|c|}{7,00} & & $\alpha_{M, A D, 1}=$ & 1,000 & & \multicolumn{2}{|l|}{$\rho_{A D, 1}=$} & $1-s z_{1}=61,0 \%$ & \\
\hline c & CEM I 42,5 N & \multicolumn{2}{|c|}{693} & & & & & $\rho_{c}=$ & 3076 & & $s w_{c}=1,35 \%$ \\
\hline $\mathbf{K}_{\text {virt }}$ & limestone filler & \multicolumn{2}{|c|}{250} & & $\alpha_{M, \text { Kvirt }, 1}=$ & 1,000 & $\phi_{K, 1}=80,0 \%$ & $\rho_{K, 1}=$ & 2699 & & $s w_{K, 1}=0,50 \%$ \\
\hline \multirow{8}{*}{$\mathbf{A G}_{\text {virt }}$} & \multirow{2}{*}{$0 / 4_{\text {virt }}$} & \multirow{2}{*}{\multicolumn{2}{|c|}{2278}} & & \multirow{2}{*}{$\alpha_{M, A G v i r t, 1}=$} & \multirow{2}{*}{0,375} & \multirow{2}{*}{$\phi_{A G, I}=$} & $\rho_{\text {AG,fine, }}=$ & 2550 & \multirow{2}{*}{$w_{A G, 1}=$} & \multirow{2}{*}{$s w_{A G, 1}=0,19 \%$} \\
\hline & & & & & & & & $\rho_{\text {AG,coarse } 1}=$ & 2609 & & \\
\hline & \multirow{2}{*}{$4 / 8_{\text {virt }}$} & \multirow{6}{*}{6072} & 1279 & & \multirow{2}{*}{$\alpha_{M, A G v i r t, 2}=$} & \multirow{2}{*}{0,211} & \multirow{2}{*}{$\phi_{A G \text { vir }, 2}=\quad 0,3 \%$} & $\rho_{A G, \text { fine, } 2}=$ & 2550 & \multirow{2}{*}{$w_{A G, 2}=$} & \multirow{2}{*}{$s w_{A G, 2}=0,96 \%$} \\
\hline & & & & & & & & $\rho_{A G_{1} \text { coarse } 2}=$ & 2640 & & \\
\hline & $8 / 16_{\text {virt }}$ & & 1158 & & $\alpha_{M A G v i r 3_{3}}=$ & 0,191 & $\phi_{4 G_{\text {vint } 3}=}$ & $\rho_{\text {AG. fine } 3}=$ & 2550 & $w_{A G 3}=$ & $s w_{A G 3}=1,01 \%$ \\
\hline & 18 virt & & 11ग0 & & $u_{M, A G v i r, 3^{-}}$ & 0,191 & $\varphi_{\text {AGvirt }, 3-}^{-}$ & $\rho_{\text {AG,coarse } 3}=$ & 2618 & $w_{A G, 3^{-}}$ & $S W_{A G, 3}-1,01 \%$ \\
\hline & $16 / 32$ & & 1357 & & $\alpha_{M}=$ & 0.223 & $\phi$ & $\rho_{\text {AG.fine, } 4}=$ & 2550 & $w$ & $s w=0.95 \%$ \\
\hline & & & 1531 & & $u_{M, A G v i r, 4}^{-}$ & 0,225 & $\varphi_{\text {AGvirt }, 4}^{-}$ & $\rho_{\text {AGucaarse } 4}=$ & 2620 & ${ }_{A G, 4}$ & $3 w_{A G, 4} \quad 0,9570$ \\
\hline$l$ & $\begin{array}{c}\text { air (void)-content } \\
\text { (measured) }\end{array}$ & & & 0,022 & & & & & & & \\
\hline calc & ulated concrete & $\mathrm{V}_{\text {concrete }}=$ & & $\mathrm{m}^{3}$ & $p=$ & $\mathbf{0 , 2 3 8}$ & $x=1,356$ & $\lambda_{\mathrm{AD}}=$ & 0,019 & $\chi_{\mathrm{c}}=0,736$ & $\mathrm{v} / \mathrm{c}=\mathbf{0 , 6 2}$ \\
\hline & indicators: & $\rho_{\text {concrete }}=$ & & $\mathrm{kg} / \mathrm{m}^{3}$ & $\mathrm{w}_{\text {beton }}=$ & $6,41 \%$ & & & & & \\
\hline
\end{tabular}

Table 3. Raw data from a specific batch of concrete, and the concrete composition content indicators calculated using equations (13) to (22) (evaporation was not accounted for here, $\Delta W_{e v}=0$ ).

3. táblázat Egy konkrét betonszállitmány alapadatai és a $(18)-(26)$ képletekböl számított betonösszetételi állapotjelzői (párolgással nem számoltunk, $\Delta W_{e v}=0$ )

\section{Data from the observations made at the mixing plant: experiences and conclusions}

We began to collect and analyse the data from measurements and observations at the mixing plant in 2008. The data constituted the basic input for the data processing. At the end of the first year an interim evaluation was carried out. Observation data for compressive strength in 114 cases and for consistency in 119 cases were evaluated. The ranges of the concrete composition content indicators from the first year are shown in Table 4, while the structural compositions of the batches of concrete are presented graphically in Fig. 2.

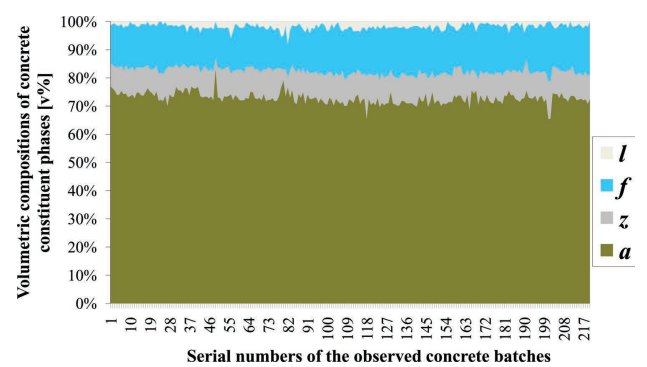

Fig. 2. Volumetric compositions of concrete constituent phases during observations 2. ábra A betonalkotó fázisok térfogatos összetételei a megfigyelések során

In the first period between 2008 and 2009, we were able to analyse the effects of several types of cement and several waterreducing agents in the case of concrete compositions with different $p$ paste ratio and $x$ fluid-paste powder volume ratios. With regard to the effect imposed on concrete compressive strength by the type of cement used, beyond the traditionally accepted influence (i.e. water-cement ratio is closely related to the compressive strength), we also found that the cement dosage ratio is a factor of at least of equal importance, and when we take the two factors together, the estimation of the compressive strength has a high degree of accuracy, in the case of mixes with identical air contents in the observed $p-x$ ranges. We also found that the effect imposed on compressive strength by the $x$ fluid-powder volume ratio is very similar to that of $\mathrm{w} / \mathrm{c}$.

\begin{tabular}{lccccc} 
& $\mathbf{p}$ & $\mathbf{x}$ & $\chi_{\mathrm{c}}$ & $\lambda_{\mathrm{AD}}{ }^{*}$ & $\mathbf{l}$ \\
$\mathbf{m i n}$ & 0,159 & 1,140 & 0,562 & 0,000 & 0,000 \\
\hline $\boldsymbol{m a x}$ & 0,327 & 3,874 & 1,000 & 0,031 & 0,076 \\
\hline average & 0,265 & 1,828 & 0,856 & 0,012 & 0,007 \\
\hline st. dev & 0,02 & 0,33 & 0,09 & 0,01 & 0,01 \\
\hline
\end{tabular}

Table 4. Concrete composition content indicators from the first period of manufacturing plant observations

4. táblázat A betonösszetételi állapotjelzők alakulása a gyártóüzemi megfigyelések elsö szakaszában

For illustration purposes, Figs. 3 to 6 show the compressive strength relations observed. It can be seen at the identically scaled figures that the approximation functions inserted beside the measured compressive strength values do not run in parallel with the presented CEM I 42.5 and CEM III/A 32.5 cements, which is of course no surprise, but there is one important conclusion to be drawn, which has already been stated by Ujhelyi [7] in his findings on the water sensitivity of cements, and which is summarised Kausay in his comprehensive essay on the water-cement ratio [11] as: "By the water sensitivity of cements Ujhelyi means that different types of cement behave in different ways when the dosage of water is different (and therefore the water-cement ratio is different), for example, there are certain cements whose compressive strength decreases more rapidly than that of other cements as the dosage of water increases, and vice versa." In other words, cements cannot be typified in absolute figures (such as nominal compressive strength) but only with their particular characteristics, which in turn - as we can add with reference to our own observations depend on the concrete composition content indicators. It is not only the effect of cements, however, that can be described with characteristics, but also the effect of water-reducing agents. 


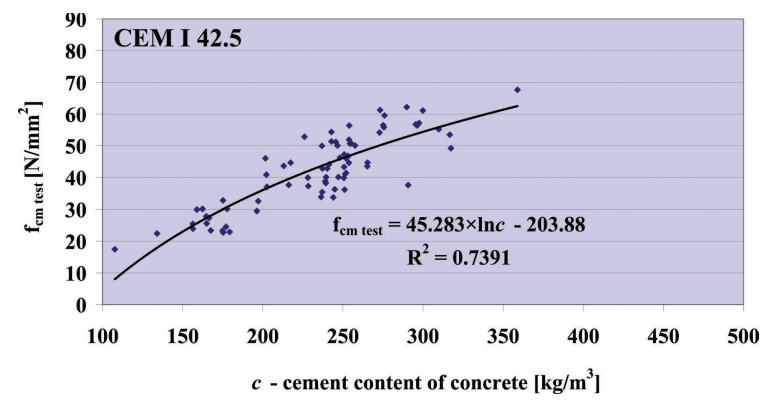

Fig. 3. The relationship between compressive strength and quantity of CEM I 42.5, based on observation data taken between 2008-2009

3. ábra A szilárdság függése a CEM I 42,5 mennyiségétöl a 2008-2009 közötti megfigyelési időszak adatai szerint

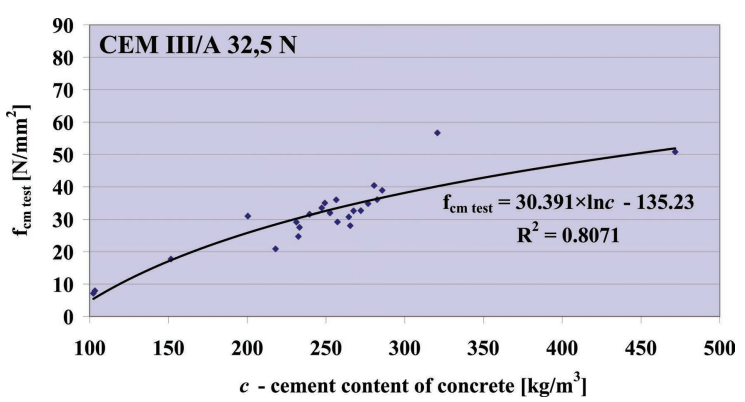

Fig. 4. The relationship between compressive strength and quantity of CEM III/A 32.5 , based on observation data taken between 2008-2009

4. ábra A szilárdság függése a CEM III/A 32,5 mennyiségétól a 2008-2009 között megfigyelési időszak adatai szerint

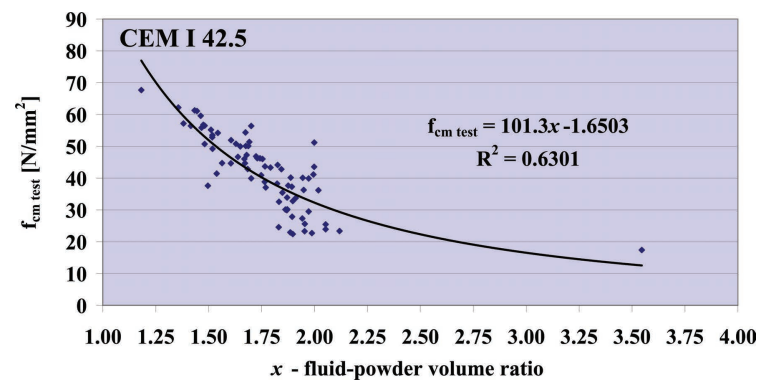

Fig. 5. Relationship between compressive strength and the $x$ fluid-powder volume ratio for CEM I 42.5, based on observation data taken between 2008-2009

5. ábra A szilárdság függése CEM I 42,5 esetében az x folyadék-por térfogati tényezötöl a 2008-2009 közötti megfigyelési időszak adatai szerint

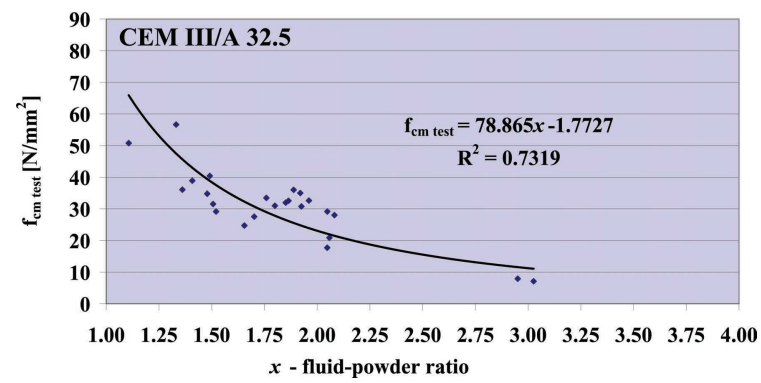

Fig. 6. Relationship between compressive strength and the $x$ fluid-powder volume ratio for CEM III/A 32.5, based on observation data taken between 2008-2009

6. ábra A szilárdság függése CEM III/A esetében az x folyadék-por térfogati tényezőtól a 2008-2009 közötti megfigyelési időszak adatai szerint

Space limitation of present paper let us illustrate only on a few diagrams the widely differing effects experienced with certain water-reducing agents - compared both to each other and with concrete compositions without agents (Figs. 7 to 10).
It is indeed true that the water-reducing capacity of the agents depends on the concrete composition content indicators, so in these instances it is not enough to simply carry out the essential single-factor impact assessment (generally restricted to $\mathrm{w} / \mathrm{c}=0.5)$ that is suggested in the harmonised EN product standards.

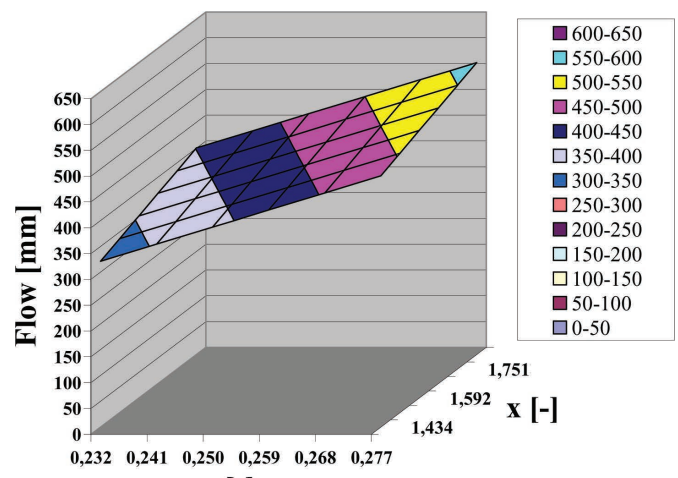

p [-]

Fig. 7. The effect of a normal range water-reducing agent $\left(\lambda_{A D}=1.05 \% \mathrm{v} / \mathrm{v}\right)$ on the flow of fresh concrete

7. ábra Erös vízcsökkentö $\left(\lambda_{A D}=1,05 \%\right.$ v/v) adalékszer hatása a betonkeverékek terüléseire

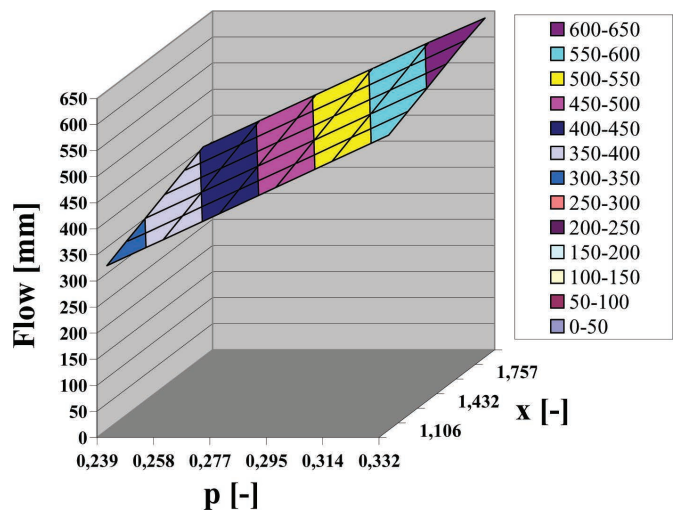

Fig. 8. The effect of a high range water-reducing agent $\left(\lambda_{A D}=1.23 \% \mathrm{v} / \mathrm{v}\right)$ on the flow of fresh concrete

8. ábra Kiváló vízcsökkentö $\left(\lambda_{A D}=1,23 \%\right.$ v/v) adalékszer hatása a betonkeverékek terüléseire

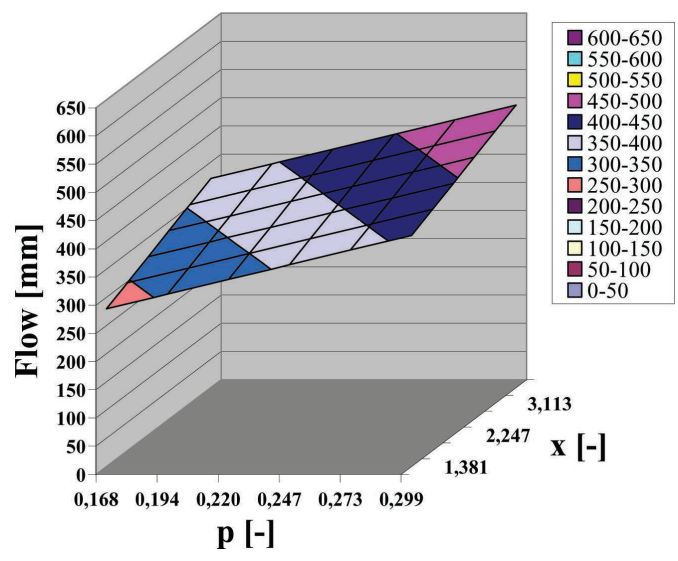

Fig. 9. Consistencies without water-reducing agents in the case of maximum size of aggregate $D_{\max }=24 \mathrm{~mm}$

9. ábra Vízcsökkentő adalékszer nélküli konzisztenciák $24 \mathrm{~mm}$ legnagyobb szemnagyságú adalékanyagok esetén 


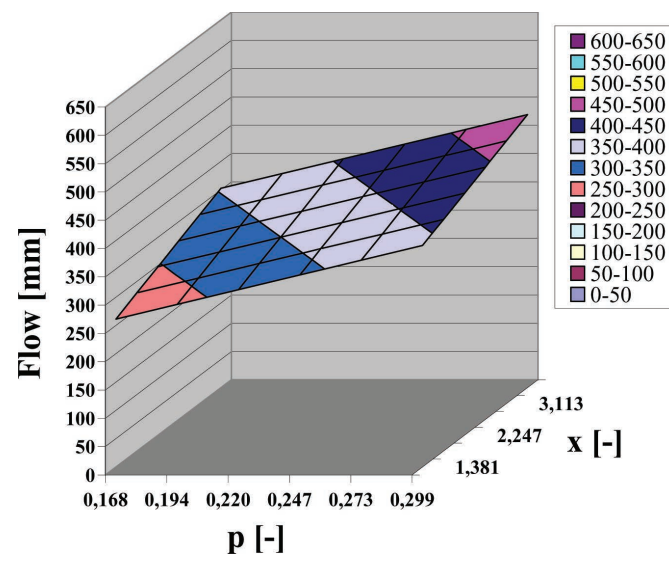

Fig. 10. Consistencies without water-reducing agents in the case of maximum size of aggregate $D_{\text {max }}=16 \mathrm{~mm}$ 10. ábra Vízcsökkentő adalékszer nélküli konzisztenciák 16 mm legnagyobb szemnagyságú adalékanyagok esetén

\section{Acknowledgements}

The author wishes to express his gratitude to the Augusztin Betongyártó Ltd. concrete mixing plant and particularly to $\mathrm{Mr}$. Bálint Augusztin, CEO.

\section{References}

[1] Szalai K. - Huszár Zs. - Spránitz F.: Betonszerkezeti EU szabványok hazai bevezetése, alkalmazása, 6. fejezet: HSC/HPC betonok és hídépitési alkalmazása. Magyar Betonszövetség, Magyar Betonelemgyártó Szövetség, Magyar Építőanyagipari Szövetség, Budapest, 2005.

[2] Zsigovics, I.: Self Compacting Concrete, Newest Revolution of Concrete Technology 3. Influence of limestone powder on the properties of fresh and hardened concrete. Vasbetonépítés, 2004/3, pp. 72-79.

[3] Sulyok, T.: Metróállomások épitése az Etele téren és a körtéren. Beton, XIV. évf. 10. szám, 2006. október, pp 26-27.

[4] Sulyok, T.: Beszámoló az M6 autópályán épülő alagutakról - betontechnológus szemmel. Beton, XVII. évf. 5. szám, 2009. május, pp 10-13.

[5] Spránitz, F.: Érdemes-e küszködni az NT betonokkal? 4. rész - avagy milyen nemüek a nagy teljesitőképességü (NT) betonok? Beton, XVII. évf. 1. szám, 2009. január, pp 3-7.

[6] Powers, T. C. 1900-1997: Bibliography, PCA Library Bibliography No.33 (LB33), Portland Cement Association, 2007
[7] Ujhelyi, J.: Betonismeretek. Műegyetemi Kiadó. Budapest, 2005.

[8] MÉASZ ME-04.19:1995 Müszaki eloirrás beton és vasbeton készitésére. Magyar Építőanyagipari Szövetség, Budapest, 1995.

[9] Spránitz, F.: Magas- és mélyépitési termékek újszerü gyártástechnológiái. Beton, XVI. évf. 2. szám, 2008. február, pp 14-16.

[10] Powers, T. C.: Absorption of Water by Portland Cement Paste during the Hardening Process. Industrial and Engineering Chemistry, July 1935, Vol. 27, No. 7, pp 790-794.

[11] Kausay, T.: Víz-cement tényezö, viz/cement tényezö. Beton, XVI. évf. 4. szám, 2008. április, pp 8-11.

Ref.:

Gyula Pekár: Simple basic model for concrete and its application. 1. Content indicators of concrete mixtures and mixing plant observations

Építőanyag, 65. évf. 2. szám (2013), 52-60. p. http://dx.doi.org/10.14382/epitoanyag-jsbcm.2013.12

\section{Betonkeverékek egyszerúsített alapmodellje}

és alkalmazása.

1. rész: Betonösszetételi állapotjelzők

és gyártóüzemi megfigyelések

A betontechnológia állandó feladata a betonalkotó anyagok hatásainak vizsgálata. E hatások elemzése és a tapasztalt összefüggések értelmezése során idôrốl idôre érdemes átgondolni azokat a modelleket, amelyekben a tapasztalt hatásokat értelmezzük. Ha szükséges, akkor finomításokkal is kell élnünk, hogy az új anyagok megjelenésével a betontervezés alapjául szolgáló modellek is lépést tarthassanak. A cikk a betonkeverékek összetételének egy leegyszerúsített alapmodelljét mutatja be, bevezetve a betonösszetételt egyértelmúen meghatározó, dimenzió nélküli állapotjelzôket, amelyekrổl feltételezhetô, hogy a betonok teljesítményjellemzóit befolyásolják, így vizsgálatuk szükségszerû. A modell kidolgozását egy gyártöüzemi megfigyelési sorozat indította el. Ez a gyártóüzemi megfigyelés szolgált az elsố alapadat-forrásként a betonkeverékek egyszerúsített alapmodelljéhez, amely a dimenzió nélküli beton összetételi állapotjelzôk bevezetésével újszerú lehetôségeket kínál a friss és megszilárdult betonkeverékek teljesítményjellemzôit befolyásoló hatások vizsgálatára.

Kulcsszavak: betontechnológia, betonösszetétel tervezése, betonösszetételi állapotjelzôk

\section{TRANSCEND CONFERENCE Water Transport in Cementitious Materials}

November 3-6, 2013, Guildford, UK http://www.nanocem.org/TRANSCEND-MC-ITN

\section{Venue:}

The conference will be held at the conference center, Radisson Blu Edwardian Guildford Hotel in Guildford, UK.

\section{TRANSCEND Research themes and projects:}

Modelling - The theme comprises five projects that systematically build a theoretical understanding of water dynamics in cements and concretes at a hierarchy of length scales: Molecular dynamics study of water exchange between inter-sheet and gel pore in cement analogues; Moisture transport in random media: Calcium Silicate Hydrate (C-S-H); Lattice Boltzmann modeling of water dynamics in cement paste; The role of microcracks in concrete on water transport; Drying-wetting cycles: effects on moisture transport within cementitious materials.

Experimental - The theme comprises six projects that build the experimental parameter database such as characterisation of materials and transport coefficients needed as input to the modelling developed in Theme Modelling: Wetting and drying cycles: effects of hysteresis on transport; Study of white cement pastes by nuclear magnetic resonance (NMR); Relationship between composition, structure and morphology in C-S-H; nuclear magnetic resonance imaging and relaxation analysis of cement based material; Cryoporometry characterisation for cement based materials; Characterisation of microcracks in concrete and transport in concrete.

Validation - The theme comprises four projects that together validate the output at the different length scales of the modelling programme: Transport and water dynamics in the nanopores of C-S-H; Impact of mineralogy on the water balance of cement paste; Validation of concrete water transport tests by $1 \mathrm{H}$ magnetic resonance profiling; Validation of modeling with respect to drying and shrinkage. 